\title{
Claims Relating to Public Contracts
}

As pointed out elsewhere, public contracts in Western countries tend to be governed by specific rules with the main objective of awarding specific powers to public contractors, even in common law countries such as the United States and England and Wales where those rules derive from statutory regulations or standard terms. ${ }^{1}$ Nonetheless, situations may vary to a certain extent from one country to another. Contrary to common law countries, civil law countries such as France, Spain, Portugal and Finland reproduce the public and private law divide when it comes to public contracts. Other civil law countries such as Germany, Denmark, Poland and Sweden, even those with distinct administrative courts, would consider public contracts a common legal transaction and therefore adjudicate those contracts in civil courts with the consequence that they are governed by (private) contract law. France is an interesting example of the second category in relation to most public contracts - that is, contracts signed by the administration are public law contracts (contrats administratifs) subject to specific rules, set most of the time by the case law of the Conseil d'Etat, whose aim is to protect the public interest. Another consequence of the jurisdiction of the administrative courts lies in the existence of specific remedies, but both consequences follow from the contract's characterisation as a contrat administratif.

\subsection{WHAT IS A PUBLIC LAW CONTRACT?}

The predominance of the criterion of intérêt public (public interest) in French administrative law drove the Conseil d'Etat to build its case law upon the

1 P. Craig, 'Specific Powers of Public Contractors', in R. Noguellou and U. Stelkens, eds., Droit comparé des contrats publics/Comparative Law of Public Contracts (Bruxelles: Bruylant, 2010), p. 173 . 
public and private law divide even for contracts. Indeed, the unilateral act was never the only way for public authorities to act (administrer). Unlike most civil law countries, which tend to consider contracts as transactions relating to private law, French law put in place specific rules for public contracts long before the creation of the 'new' Conseil d'Etat in 1799. ${ }^{2}$ Even today, public authorities are free to decide whether to contract out or to arrange in-house services and act unilaterally, and this principle initially set by the case law is now enshrined in the Code de la commande publique (CCP), which consolidates rules applicable to public procurement contracts and to concessions since its creation by Ordinance of 26 November 2018 and Decree of 3 December 2018. 3 So it is very unlikely that the French parliament would introduce a system equivalent to the compulsory competitive tendering used in the 1980s and the 1990s in the United Kingdom for the reason that it is contrary to the tradition and spirit of French administrative law. In addition, although public contracts have been fostered during the second half of the twentieth century as a way to promote citizens' acceptance of public policies and often replace unilateral acts, the Conseil d'Etat has sometimes re-characterised those so-called contrats as unilateral acts when the contract is just a façade. ${ }^{4}$

However, the Conseil d'Etat also considers that not every public contract serves the public interest and distinguishes between those having a sufficient link with the public interest whose adjudication is assigned to administrative courts and subject to public law rules and those with no such a link which are assigned to civil courts and subject to private law rules.

Therefore, in practice, public contracts must often first be characterised as contrats administratifs - that is, public law contracts - in order not only to know the competent court in case of litigation, but also the applicable rules. The exception is where there are written legal rules applicable independently of this characterisation, for instance on transparent award rules.

However, the legislator sometimes intervenes to assign adjudication for specific types of public contract to either administrative or civil courts regardless of the criteria set by the case law.

2 J.-L. Mestre, Introduction historique au droit administratif (Paris: PUF, 1985), esp. nos. 49, 97 and 151 .

3 Art. Li CCP: "The concessionaries and the authorities granting a concession may choose freely, to meet their needs whether to use their own methods or to have recourse to a public procurement contract.'

4 CE 20 March 2000, Mayer et Richer, no. 202295, AJDA 2000, 756, note Jegouzo, regarding the charte des thèses and the relationships between $\mathrm{PhD}$ students and their supervisors. 


\subsubsection{Criteria Laid Down by Administrative Courts}

Modern criteria were set by the Conseil d'Etat at the beginning of the twentieth century and are twofold: some criteria relate to the existence of a public service mission, whereas others relate to the presence of a clause which involves a regime going beyond private law.

\subsubsection{Criteria Linked to a Public Service Mission}

The case law refers to service public ('public service' meaning a service in the public interest) in different ways. The most obvious example is when the execution of a public service by the contractor of the administration is the very subject matter of the contract, as was the case in Thérond. ${ }^{5}$

The city of Montpellier and Mr Thérond entered into a contract for the capture and impounding of stray dogs and the removal of dead animals. A dispute arose and Thérond tried to obtain the termination of the contract and damages. The Conseil d'Etat confirmed the jurisdiction of the administrative courts on the ground that by contracting out 'the city of Montpellier acted with a view to the hygiene and safety of the population and therefore had the aim of providing a public service'. On the substance, it ruled in favour of Thérond. Since the monopoly created by the contract was illegal, the contract had to be terminated and damages awarded to Thérond. Soon after, the service public criterion was discarded in favour of another criterion based on the presence of a clause going beyond private law (the clause exorbitante; see Section 1.1.2). But the service public criterion saw a revival in the mid-1950s. In October 1944, Mr and Mrs Bertin were asked by the administration to take care of Russian refugees. The Conseil d'Etat in 1956 considered this as the implementation of a contrat administratif, in spite of the absence of any written contract, on the ground that they were fulfilling a public service mission. ${ }^{6}$

The very same day, the Conseil d'Etat issued a second example of identifying a public law contract by reference to a public service mission, although the contract did not entrust the contractors with the mission itself, but they were a means of delivering a public service. The government had undertaken by contract to carry out reforestation work on land belonging to private owners, which led to a fire on several properties, including those of the Grimouards. The Conseil d'Etat had jurisdiction since the contract was of a public law

5 CE 4 March 1910, no. 29373, Leb. 193.

6 CE Sect. 20 April 1956, Époux Bertin, no. 98637, Leb. 167. 
nature in that the contract did entrust public works to the administration. ${ }^{7}$ This idea was later extended outside the scope of public works. ${ }^{8}$

Finally, the public service notion is also used to identify a public law contract when it comes to contracts made with employees of the administration. In principle, public agents have a status rather than a contract. But for reasons of flexibility, the legislator regularly adds exceptions. The question arises whether those contracts are of public law nature, subject to limited rights and obligations set by decrees ${ }^{9}$ and by the case law of the Conseil d'Etat concerning general principles of law such as the ban on sacking a pregnant woman unless she committed a serious fault and the duty to pay a minimal wage, ${ }^{10}$ or of private law nature and therefore subject to the Labour Code. Case law makes a distinction between the participation of the agent in a service public administratif, which is the normal nature of national or local public services such as public universities or public hospitals, and in a service public industriel et commercial, which is similar to private economic activities - for example, public transportation, water distribution or sewage. In the first case, the contract of the agent is of public law nature ${ }^{11}$ and the agent called an agent public contractuel; in the second, the contract is of a private law nature unless it concerns the head of the service or the public accountant. ${ }^{12}$

\subsubsection{Criteria Based on a Clause Unusual in Private Law}

The second alternative criterion was set in 1912 by the Société des granits porphyroides des Vosges case, which was decided on the conclusions of the commissaire du gouvernement Léon Blum twenty-four years before he became the first socialist Prime Minister (or Président du conseil as the position was then called). The Conseil d'Etat dismissed the claim as brought before the wrong court and ruled the following:

The contract between the city and the company was exclusive of any work to be carried out by the company and had as its sole object supplies to be

7 CE Sect. 20 April 1956, Consorts Grimouard, no. 33961, Leb. 168.

8 TC 24 June 1968, Société Distilleries bretonnes, no. o1917, D. 1969, 116.

9 Decree of 17 January 1986 for agents of the State or its public establishments, decree 15 February 1988 for agents of local authorities or their public establishments and decree 6 February 1991 for agents of public hospitals.

$1 \circ$ Respectively CE Ass. 8 June 1973, Peynet, no. 80232, Leb. 406 and CE Sect. 23 April 1982, Ville de Toulouse c Aragnou, no. 36851 , Leb. 152.

${ }^{11}$ TC 25 March 1996, Préfet de la région Rhône-Alpes, no. 03000, Leb. 535, which abandoned the previous distinction between direct and indirect participation in the service public administratif.

12 CE 26 January 1923, De Robert Lafrégeyre, no. 62529, Leb. 67; CE Sect. 8 March 1957, Jalenques de Labeau, no. 15219, Leb. 158. 
delivered in accordance with the rules and conditions of contracts between individuals.

The ruling made no reference to the absence of a public service mission, which was interpreted as an abandon of this criterion. The 'rules and conditions of contracts between individuals' reference was later interpreted as meaning the absence in the contract of any clause exorbitante du droit commun (droit commun meaning private law). In other words, every time a court can spot a clause going beyond what is permissible in a private law contract, the contract is deemed of a public law nature and administrative law applies. For a long time, the case law did not define precisely what this meant. But scholars referred to it either giving exceptional powers to the administration or more generally as unusual in private relationships. It is true that most of those clauses illustrate the former - for instance, a clause which allows the administration to terminate a contract for reasons of public interest ${ }^{13}$ or which imposes strong powers of control over the private party. ${ }^{14}$ But the case law also illustrates a wider concept: a tax-exemption clause is exorbitante ${ }^{15}$ just as is a clause which secures to local inhabitants the benefit of preferential conditions for using a ski lift service. ${ }^{16}$ On the contrary, a clause is not exorbitante either where a company commits to exporting local products and creating jobs, ${ }^{17}$ or where the public owner is allowed to take back the use of a leased building without compensation at any time and for any reason, only subject to one month's notice. $^{18}$

The broader concept of clauses unusual in private relationships means that such clauses are not absent in contracts signed between private parties. This is the reason the Tribunal des Conflits decided to change the formulation: it does not refer to them anymore as 'clauses derogating from private law' but as clauses 'which, in particular by virtue of the prerogatives granted to the contracting public entity in the performance of the contract in the public interest, imply that it falls within the regime of public law contracts'. ${ }^{19}$

Having such a clause or, alternatively a link with a public service mission, contrats administratifs must, in principle, also include at least one public authority as a party to the contract. But it may happen that such a public law contract is characterised by the courts as 'private'. This is the case when one

\footnotetext{
TC 16 January 1967, Société du vélodrome du Parc des Princes, no. o1895, Leb. 652.

TC 22 June 1998, Agent judiciaire du Trésor c Miglierina, no. 03003.

TC 2 July 1962, Consorts Cazautets, no. 1776, Leb. 823.

TC 6 June 2016, Commune d'Aragnouet, no. C4051.

TC 11 May 1992, Société Office Maraîcher fruitier, no. o2696, Leb. 485.

TC 20 February 2008, Verrière, no. $\mathrm{C}_{3} 623$.

TC ${ }_{13}$ October 2014, Société Axa France IARD, no. $\mathrm{C}_{396}$, Leb. 471.
} 
party acts on behalf of a public authority because it previously signed an agency $\operatorname{contract}^{2 \circ}$ or when one of the private parties acts on behalf of a public authority, a blurred concept which encapsulates several particular hypotheses where the private party appears to be a sort of tool in the hand of a public authority albeit with no proper agency contract. ${ }^{21}$

The Société des granits porphyroïdes des Vosges case also implicitly ruled as shown by the conclusions of Léon Blum - that a simple decree could not be opposed to the criteria set by the Conseil d'Etat. ${ }^{22}$ By setting the criteria of a public law contract, the Conseil d'Etat interprets the principle of separation of administrative and judicial authorities laid down by law and no decree can overturn this interpretation. Of course, the legislator can undo what it has laid down in a previous law. As we have seen previously, public contracts are not in the field of the jurisdiction of administrative courts guaranteed by the Constitution as interpreted by the Conseil constitutionnel. ${ }^{23}$

\subsubsection{Criteria Laid Down by the Legislator}

It is sometimes difficult to identify the reason the legislator assigns contracts either to administrative courts or to civil courts. This is because either some of the relevant decisions were made a long time ago or by way of secondary legislation (ordonnances) with no trace of the travaux préparatoires. A chronological order offers greater simplicity and clarity than would a logical one, which would be hard to find.

The Law of 28 pluviôse An VIII (17 February 1800) assigned two types of public contracts to the administrative courts (or more precisely to the conseils de préfecture which were created simultaneously): public procurement contracts related to public works and selling of real estate by the government. The former may be explainable by the willingness to allocate litigation, already allocated to the Conseil du Roi before the Revolution, to local administrative courts because they were very numerous. ${ }^{24}$ The latter is explained by the desire to avoid the risk that ordinary judges - that is, civil courts, would declare void contracts selling real estate formerly owned by the Catholic Church on the ground that they were illegally acquired by the government during the French Revolution. ${ }^{25}$ The former was repealed 'by accident' when the latter was

20 CE 27 May 1957, Artaud, no. 32818, Leb. 350.

${ }^{21}$ See F. Lichère, 'L'évolution du critère organique du contrat administratif, RFDA 2002, 341.

22 CE 31 July 1912, no. 30701, Leb. 909.

23 CC decision no. 86-224 DC of 23 January 1987, Competition Law, Rec. 8, Chapter 5, note 1.

24 Mestre, Introduction historique, p. 198.

25 K. Weidenfeld, Histoire du Droit administratif (Paris: Economica, 2010), p. 129. 
included in 2006 in art. L3331-1 of the newly published Code de la propriété des personnes publiques (CGPPP) but the Conseil d'Etat still applies the rule without any legal text since the content of the notion of travaux publics derives only from its case law. ${ }^{26}$

Décret-loi 17 June 1938, now codified in art. L2331-1 CGPPP, allocated to administrative courts litigation in relation to the occupation of the domaine public permitted by public authorities or their concessionaries. As was seen in Chapter 5, Section 2.2, this public domain includes real estate owned by public authorities which is dedicated to public use or to public service missions. It is subject to rules protecting them from third parties - for example, it is inalienable - or from public authorities themselves - for example, there are no legal possibilities to sell them unless a formal decision to decommission them is adopted. The idea of the décret-loi was to unify litigation since private use of the public domain might also take the form of a license which can only be granted by a public authority and litigation over this belongs to administrative courts. ${ }^{27}$ For obscure reasons, the Tribunal des Conflits ruled that the term concessionaries should be interpreted restrictively as meaning concessionnaires de service public and such a position, constantly reaffirmed, is still often criticised as contrary to the initial intent. ${ }^{28}$

The Law of 11 December 2001 extended the jurisdiction of administrative courts to litigation involving a public authority (with the exception of établissements publics industriels et commerciaux) and dealing with public procurement contracts of any sort, and not just public works as under the Law of 28 pluviôse An VIII. It appears that simplification by way of unification was the reason for this law, which now extends to all public procurement contracts signed by any public authorities since the Ordinance 23 July 2015 and also to concessions signed by public authorities since the Ordinance 29 January 2016, both of them now codified in the Code de la commande publique.

Article L442-5 of the Education Code, resulting from the Law of 5 January 2005, considers that teachers attached those private educational establishments which entered into contract with the government are bound to the state by a public law contract.

The Energy Code assigns two types of litigation to administrative courts. Article L314-7, resulting from art. 88-III of the Grenelle II Law of 12 July 2010, categorises mandatory electricity purchase contracts as public

E. Glaser in his conclusions on CE, 7 August 2008, SAGEP, no. 289329, Bulletin juridique des contrats publics 2009, no. 62, p. 41 .

27 P. Blanquet, 'Le sous-contrat. Étude de droit administratif (Thesis Paris 2, 2020), p. 385.

28 See, for example, N. Foulquier, Droit administratif des biens, 5th ed. (Paris: Lexisnexis, 2019), p. 394 . 
contracts. $^{29}$ Such a categorisation was clearly made as a way to avoid civil courts in a particular context. In autumn 2009, the government announced that the price of the electricity produced from renewable energy would be reduced in January, which led to a rise in projects of 500 per cent compared to the precedent autumn. To combat this windfall (effet d'aubaine) phenomenon, the government in January 2010 issued an order stating that the new price would be applicable when the contract was signed and not when the prior request for connection was made. The latter would have meant that the former high price applied for twenty years. The government feared that civil courts would undermine this order by application of art. 1583 of the Civil Code according to which the sale is complete as soon as the thing and the price have been agreed upon. However, the Tribunal des Conflits was able to rule in 2010 that this categorisation could not apply to contracts signed before the law was passed without infringing the European Convention on Human Rights (ECHR). ${ }^{30}$ This was and is still the only application of the ECHR by this court. For the contracts signed after the law, the Conseil d'Etat rejected a question préalable de constitutionnalité (QPC) on the grounds that 'these provisions have neither the object nor the effect of modifying the economy of the contracts in question, the legal regime of which being entirely determined by the law'.31 In addition, art. 104 of the Law of 17 August 2015 introduced into the Energy Code art. L314-24, which also provides that remuneration supplement contracts concluded by Electricité de France (EDF) with renewable energy producers who sell their electricity on the wholesale market and not to EDF are public law contracts.

Finally, the transformation of the Société Nationale des Chemins de fer français (SNCF) into a private company (as a public capital company) by the Ordinance of 3 June 2020, which came into force on 1 January 2021, maintained the jurisdiction of administrative courts to rule on public procurement contracts litigation and also on contracts related to the occupation of domaine public (art. L2111-9-1 of the Code des transports). It is assumed that the government wishes the SNCF to keep its prerogative powers attached to public law contracts. By contrast, it could still be the case that civil courts are competent for certain litigation and this may affect the normal jurisdiction of administrative courts.

\footnotetext{
29 Electricite de France is obliged to buy electricity produced from renewable energy.

30 TC 13 December 2010, Société Greenyellow, no. C3800, Leb. 592.

${ }^{31}$ CE 5 June 2013, Société MSO Sablirot, no. 366671.
} 
The Rural Code entrusts the judicial courts with the contractual litigation of rural leases, including leases concluded by public authorities.

Under art. L7121-2 of the Labour Code, 'any contract by which a natural or legal person secures, for remuneration, the assistance of a performing artist with a view to its production, is presumed to be an employment contract'. It is therefore a private law contract even if it is concluded by a public person to fulfil a public service mission. ${ }^{32}$

The two examples mentioned earlier aimed at creating homogeneous litigation arrangements whatever the status of the employer, similar to those discussed in Chapter 5, Section 2.5. The situation of the last exception regarding établissements publics industriels et commerciaux created by a law is different. The Tribunal des Conflits interprets such a creation as a willingness to submit those public persons to private law, because the public enterprises are often subject to competition law, and it recognises very limited exceptions. A recent formulation of the exceptions widens them a little bit:

Unless otherwise provided for by law, when a public establishment has the status of an industrial and commercial establishment, contracts concluded for the needs of its activities fall within the jurisdiction of the civil courts, with the exception of those containing clauses derogating from private law or falling under a regime derogating from private law as well as those relating to those of its activities which by their nature fall under the prerogatives of public authorities. 33

9.2 SPECIFIC RULES APPLICABLE TO PUBLIC LAW CONTRACTS

\subsubsection{Rules Applicable to the Formation of the Contract}

The so-called transparency principle is the underlying principle of the award rules now set at an EU level by specific directives regarding competitive open tendering, which have had some effect on French law, as we will see in the conclusion of this chapter. But the scope of those rules diverges from the scope of contrats administratifs. For one thing, despite the expansion of the principle beyond its traditional scope that is, public procurement contracts signed by the administration - not all public law contracts are bound to respect such a duty of transparency. The duty certainly extends to concessions and to occupation of the public

32 TC 17 June 2013, Olteanu, no. C3910.

33 TC 7 April 2014, Société Services d'édition et de ventes publicitaires, no. C3949, and compare TC 16 October 2006, Caisse centrale de réassurance, no. $\mathrm{C}_{35}$ o6, Leb. 640. 
domain ${ }^{34}$ but, for instance, neither to the occupation of domaine privé, nor to the sale of real estate belonging to public authorities, except for property belonging to the state. ${ }^{35}$ By contrast, due to the influence of $\mathrm{EU}$ law the transparency rules do not apply only to public law contracts, as seen in the conclusion to this chapter. So, the peculiarities of the formation of contrats administratifs lie very much more in the case law of the Conseil d'Etat than in the rules regarding the award of some of them.

Unlike the rules applicable to the performance of the contract, the Conseil d'Etat tries here to follow the Civil Code as much as possible. As put by several rapporteurs publics, the idea is to copy and paste the Civil Code as long as public interests do not force the courts to diverge from it. This is the case to large extent when it comes to the validity of the consent and to a certain extent to the validity of the content of the contract. Article 1128 of the Civil Code states:

The following are necessary for the validity of a contract:

1. the consent of the parties;

2. their capacity to contract;

3. content which is lawful and certain.

Their decisive character is assessed in the light of the person and of the circumstances in which consent was given.

We will focus on the validity of the consent and the validity of the content. The capacity of public authorities is similar to their competence when they adopt unilateral administrative acts, as was discussed in Chapter 7 , Section 1.2.

\subsubsection{Validity of the Contractual Consent}

The civil law insists on the free will to consent. The Civil Code states in art. 1129 that 'one must be of sound mind to give valid consent to a contract' which is then expressed by the need to identify any defects in consent (vices $d u$ consentement). Article 1130 adds that 'Mistake, fraud and duress vitiate consent where they are of such a nature that, without them, one of the parties would not have contracted or would have contracted on substantially different terms.' This formulation comes from the reform of the (private) law of contracts introduced in 2016, which made clear what was disputed for a long

34 Art. R2122-1 Code général de la propriété des personnes publiques (CGPPP) introduced by Ordinance 19 April 2017 as a consequence of the decision of the CJEU 14 July 2016, Case C-458/14, Promoimpresa Srl., ECLI:EU:C:2016:558. On the concept of domaine public see Chapter 5, Section 3.2.

35 Art. R $3211-2$ CGPPP, with exceptions in art. $\mathrm{R}_{3211-7}$ CGPPP. 
time - namely, that defects in contracts apply not only where contracts would have not been signed had the defect not occurred, but also where parties would have alternatively contracted on substantially different terms. Many civil law scholars argued that only the former should lead to the contract being declared void and never to damages. But this was disputed, other scholars claiming that the former should lead to annulment, the latter to damages and yet others that it should be for the victim to decide. ${ }^{36}$ Indeed, one cannot reconstruct what a party would have done had the defect not occurred. For instance, in a case of asbestos in a building illegally hidden by the vendor, which is fraud, would the party not have entered into the contract or instead agreed to buy it at a reduced price?

Interestingly, the case law regarding contrats administratifs was not unaware of those concerns even before the 2016 reform. The Conseil d'Etat made reference to the fraud $(d o l)$ in a 1923 case $^{37}$ and ruled in 2007 that illicit collusion for the award of a public procurement contract - a very important one regarding the building of high-speed railways from Paris to the north and to the south-east of France - was deemed a fraud and could lead the victim to choose between the annulment of the contract or damages. ${ }^{38}$ Recently it even went further by adding that the victim could choose annulment even if the contract is entirely performed and when choosing annulment, he could seek restitution, the contractor in breach being then able to claim damages on the grounds of unjust enrichment, something not yet decided by the civil courts. ${ }^{39}$ In practice, it means that the contractor is deprived of any benefits, whereas in case of damages, the private contractor must only reimburse the extra costs incurred by the public authority due to the illicit collusion.

Mistake (erreur) can be a defect of consent where it affects the substance of the contract or the person of the contractor. When it concerns the substance, it may regard the identity of the thing or its substantial qualities, ${ }^{40}$ the Conseil d'Etat being quite demanding for the latter: the sale of a stallion incapable of reproducing is not void since the contract only stipulated that it had to be 'straight and in good shape'. ${ }^{41}$ By contrast, the Conseil d'Etat ruled

$3^{6}$ F. Moderne, 'Une illustration exemplaire de la théorie du dol dans le contentieux des contrats administratifs', RFDA 2008, 109.

37 CE 14 December 1923, Société des grands moulins de Corbeil, no. 242323, Leb. 852.

$3^{8}$ CE 19 December 2007, Société Campenon-Bernard, no. 261918, Leb. 507.

39 CE 10 July 2020, Société Lacroix signalisation c Seine-Maritime, no. 420045; see F. Lichère, 'Le nouveau régime contentieux des pratiques anticoncurrentielles dans les contrats administratifs', Contrats et marchés publics, November 2020, p. 7.

$4^{\circ}$ Respectively CE 10 January 1912, Ville de Saint-Étienne, no. 34708, Leb. 22 and CE Sect. 13 October 1972, SA de banque 'Le Crédit du Nord', no. 79499, Leb. 630.

${ }^{41}$ CE 28 December 1917, Belmont, no. 58000, Leb. 878. 
in favour of a contracting authority where there was a mistake as to the person of the contractor when an administration representative thought a person was acting in his capacity of representative of a firm when it acted on his own behalf..$^{2}$

Finally, duress (violence) is explicitly mentioned by the case law of the Conseil d'Etat very rarely as it seems unlikely that an administration's representatives would use such threats and that private parties would do the same towards civil servants. Furthermore, the case law is strict on the degree of duress. An assertion by a civil servant that the administration would apply strictly' the terms of the current contract if the other party did not sign another contract was not deemed duress. ${ }^{43}$ However, duress can originate from a third party when the contractor is under excessive economic dependence to another undertaking. ${ }^{4}$

One may notice that cases are rare before administrative courts regarding the validity of consent. It is certainly explained by the fact that public contracts are made by professionals and maybe because claimants tend to focus on the procedural award rules when they exist.

Apart from the remedies available for fraud, the way the Conseil d'Etat applies the defect of consent to contrats administratifs seems to be more or less in conformity with the case law of the Cour de cassation. ${ }^{45}$

\subsubsection{Validity of the Contractual Content}

The peculiarities of public law contracts are more striking in this area because of the way the Conseil d'Etat interprets the lawfulness and certainty of the content of a contract and because of many specific public principles to take into account.

Article 1128 of the Civil Code now requires that the content must be lawful and certain. It is the result of the reform by Ordinance 10 February 2016, which deleted a well-known and much debated concept of cause du contrat which had to be certain and lawful and was covering two different aspects: the counterpart of the contract (cause objective) and the motive of contractors (cause subjective). However, the former can still be spotted in the requirement of a certain content and the latter in the new art. 1162, which reads that 'a contract cannot derogate from public policy either by its

$4^{2}$ CE 26 April 1950, Domergue, no. 83931, Leb. 813.

43 CE 4 May 1900, Héritiers du sieur Gouy, no. 81356, Leb. 319.

44 CE 21 May 1971, La cellulose d'Aquitaine, no. 79962, RDP 1973, 275.

45 B. Plessix, 'La théorie des vices du consentement dans les contrats administratifs', RFDA 2006, p. 12. 
stipulations or by its purpose, whether or not this was known by all the parties'. In addition, the previous version of the Civil Code also required a certain and lawful subject matter which seems to be included in the same articles 1128 (certain content) and 1162 (lawful content).

The case law of the Conseil d'Etat did refer to both traditional civil law concepts and still does but with some specificities. It sees an absence of 'cause' in the case of a public person who signs a contract with a company for work that has already been the subject matter of a previous contract between the same parties, a generous solution for the contracting authority which was able to claim damages. ${ }^{46}$ The Conseil d'Etat was even more generous when declaring an absence of cause where a stipulation agreed by public blood transfusion services with their insurers had the effect of excluding any compensation for the occurrence of risks during part of the term of the insurance contract. ${ }^{47}$ This somewhat wide approach seems to extend to the unlawfulness of a 'cause'. The Conseil d'Etat assimilated it to the détournement de pouvoir in judicial review $4^{8}$ but went beyond the traditional civil concept by declaring void a contract whose purpose was to implement a regulation that was itself illegal. ${ }^{49}$ In that case, such voidness benefited the private contractors. Another interesting example regards a case brought before administrative courts by the state's representative against the amendment of a concession for public car parks by which the city of Aix-en-Provence and its concessionary removed from the concession the underground car parks in order to sell them to the concessionary. ${ }^{\circ}$ The Conseil d'Etat referred to the explicit aim of the operation, clearly claimed on the city's website, that the city was trying to avoid the transfer of competence to the Métropole of Marseille by simply deleting the very object of the competence (the underground car parks!). The Conseil d'Etat ruled out the amendment on the grounds that the subject matter was illicit. One may argue that it was more a question of cause subjective, but since the motive was so explicit it somewhat contaminated the lawfulness of the subject matter itself.

\footnotetext{
CE 26 September 2007, OPDHLM du Gard, no. 259809.

CE 29 December 2000, Beule, no. 212338, Leb. 655.

$4^{8}$ CE 15 February 2008, Commune de La-Londe-lès-Maure, no. 279045 AJDA 2008, 575. See Chapter 7, Section 1.4.

49 CE 20 February 2008, Office National de la Chasse et de la faune sauvage, no. 302053, Leb. 54.

50 CE 15 November 2017, Commune d'Aix-en-Provence, no. 409728.
} 
Regarding the lawfulness of the subject matter (objet illicite), the Conseil d'Etat rarely refers to it. Apart from the Aix-en-Provence case law, it uses it only with one purpose:

[T]he principles governing the action of public authorities and persons entrusted with a public service mission preclude an authority vested with regulatory power, which is responsible for exercising that power in the general interest with regard to the various interests for which it is responsible, from undertaking, by means of a contract, to use the regulatory power conferred on it in a specific manner..$^{51}$

But even without referring to the objet illicite (unlawful subject matter), administrative courts regularly check the lawfulness of the subject matter of a contract with regard to many other public law principles. As the Conseil d'Etat often rules, public authorities may not entrust to third parties those functions which, by nature or by the will of the legislator, are not susceptible to delegation. Therefore, a contract cannot delegate the exercise of public teaching functions, including the supervision of pupils during lunchtime in state schools, ${ }^{52}$ nor administrative police functions such as the recording of parking offences. ${ }^{53}$ Apart from the principles set by the case law, it may happen that a law forbids the administration from making certain contracts. This is notably the case regarding arbitration which is by principle banned to public authorities (art. 2060 of the Civil Code) as a way to protect the competence of administrative courts and administrative law, with few exceptions for établissements publics industriels et commerciaux, PPP contracts (marchés de partenariat) or international contracts. These exceptions are under the potential supervision of administrative courts which may check whether the arbitration infringes public policy. ${ }^{54}$

In other words, if a public law contract 'cannot derogate from public policy' as it is said for private law contracts in art. 1162 of the Civil Code, public policy has its own meaning in the area of administrative law.

\subsubsection{Rules Applicable to the Performance of the Contract}

One must bear in mind the importance of standard terms and conditions, especially with public procurement contracts. Although not compulsory, they

${ }^{51}$ CE 9 July 2015, Football Club des Girondins de Bordeaux, no. 375542.

52 CE Avis, 7 October 1986 in Y. Gaudemet, B. Stirn, T. Dal Farra and F. Rolin, Les grands Avis du Conseil d'Etat, 3 rd ed. (Paris: Dalloz, 2008), no. 24.

53 CE 1 April 1994, Commune de Menton, no. 144152.

54 CE Ass. 9 November 2016, Société Fosmax, no. 388806. 
are adopted by arrêtés ministériels and most of the time incorporated into public procurement contracts. ${ }^{55}$ In such cases, they have the simple status of contractual clauses, but their importance is so high in practice that the Conseil d'Etat eventually decided to review their interpretation by lower courts even when seised as a juge de cassation. ${ }^{56}$ Other clauses - that is, specific clauses of public law contracts, are interpreted by ordinary administrative courts and this will only be quashed in case of dénaturation (gross distortion) by them. However, the striking point of French administrative law when it comes to public law contracts lies in the existence of different rules set by the Conseil d'Etat. It calls these règles générales applicables aux contrats administratifs (general rules applicable to administrative contracts). They diverge from the binding force of contracts, the French equivalent of the sanctity of contract principle. Some of them may benefit contracting authorities, others private contractors.

\subsubsection{Exceptions to the Binding Force of Contracts Benefiting Public}

Authorities

The exceptions to the binding force of public contracts can be summed up by the recognition of several unilateral powers to contracting authorities without any legal texts or contractual clauses. Furthermore, the contracting public authorities cannot renounce them by contract. ${ }^{57}$ The rationale behind these exceptional powers is that public authorities have responsibility for the public interest which sometimes must prevail over contracts. Four sets of unilateral powers are at stake: modification, suspension, sanction and termination.

The unilateral power of modification is certainly the most striking example when one compares it to the sanctity of contract principle under English law or the principle according to which contracts are the law of the parties under French private law. The very existence of this power has been disputed by several authors because they considered that the power in the founding case was actually laid down by a regulation. ${ }^{5}$ However, the Conseil d'Etat eventually made clear that it was a règle générale applicable aux contrats administratifs in $1983 .{ }^{59}$ Contrary to what is sometimes feared, such a power should not

See the last version of the six Cahiers des clauses administratives générales des marches publics issued by the arrêtés 30 March 2021.

56 CE Sect. 27 March 1998, Société d'assurances la Nantaise et l'Angevine réunies, no. 144240, Leb. 109 .

57 CE 6 May 1985, Association Eurolat, no. 41589, RFDA 1986, p. 21, concl. Genevois.

$5^{8}$ CE 11 March 1910, Compagnie générale française des tramways, no. 16178, Leb. 216.

59 CE 2 February 1983, Union des transports publics urbains et régionaux, no. 34027, Leb. 33. 
be detrimental to the other contracting party, because it has a right to financial compensation in order to restore the financial balance of the contract (l'équation financière du contrat). ${ }^{60}$ Under this principle, the unilateral modification cannot concern only financial clauses. ${ }^{61}$ Furthermore, such power is nowadays framed, for public procurement contracts and concessions, by the European directives, as we will see in the conclusion of this chapter.

Case law also permits the administration to suspend its performance of the contract if the other party does not fulfil its contractual duties. This application of exceptio non adempleti contractus is peculiar since it is not applicable to the other party, unlike in civil law, and the underlying idea is the preservation of the continuity of the public service. ${ }^{62}$

The power of sanction varies depending on the nature of the sanction. For a long time, the administration has been allowed to impose sanctions on a defaulting contractor short of terminating the contract, and this is often enriched by the case law. Indeed, the Conseil d'Etat recognised in 2016, without any legal text or clause, the power of mise en régie by which a contracting authority takes over the contractor in case of deficiency of the performance of the contract by the latter who shall pay the extra expenses (if any). ${ }^{6}{ }_{3}$ The power of sanction was so strong that for a long time the Conseil d'Etat refused to reduce excessive penal clauses benefiting public authority contractors. Since 2008, it allows such a reduction (or to raise them if derisory) 'by application of the principles underlying art. 1152 (now art. 1231-5) of the Civil Code', but only when requested by a party, contrary to the Civil Code, which allows civil courts to raise the question of their own motion. ${ }^{6}$ Regarding the termination of a public law contract as a sanction, there were two limitations. For all public law contracts, the fault must be serious (faute grave), and this is still the case. The administrative courts apply the proportionality principle and provide compensation only for equipment not amortised when returned to the public authority. ${ }^{65}$ At the same time, the Conseil d'Etat also sought to offer security for private investments for public equipment. The power to terminate was not recognised without any specific clause when a concession or any other contract involved investment in fixed

60 Craig, 'Specific Powers of Public Contractors', p. 175.

61 CE 16 May 1941, Commune de Vizille, no. 58205, Leb. 93.

62 CE 27 March 1957, Carsalade, no. 21919, Leb. 216.

63 CE Ass. 9 November 2016, Société Fosmax, no. 388806, quoted in note 54. The two parties were private, but the contract was signed at a time when Gaz de France was a public authority and the contract kept its original nature.

64 CE 29 December 2008, OPHLM de Puteaux, no. 296930, Leb. 479.

65 CE 20 March 1957, Société des Établissements thermaux d'Ussat-les-Bains, no. 33114, Leb. 182. 
equipment to be amortised over the duration of the contract. ${ }^{66}$ However, since the contractor has now an effective remedy against such termination thanks to the Béziers II case law (see Section 3), the Conseil d'Etat admits the power to terminate any public law contract for serious fault including concessions, as it has done for a long time for the power to terminate for public interest. ${ }^{6}$

The power to terminate the contract in the public interest was stated as a régle générale applicable aux contrats administratifs in 1958, but existed earlier in the case law. ${ }^{68}$ The public interest reason is widely interpreted: technical difficulties, the reorganisation of a service or the refusal to modernise public street lighting are enough. ${ }^{69}$ Even a change in the capital assets of the concessionary (a mixed capital company) of the city of Chamonix which led the neighbouring city of Saint-Gervais to gain the majority of the capital assets was admitted as such. ${ }^{70}$

The counterpart of this wide acceptance of termination is the full compensation of the contractor, which includes damnum emergens and lucrum cessans. ${ }^{71}$ The Conseil d'Etat recently set an exception but about a peculiar public interest: serious illegality of a contract (grave irrégularité) can now justify a unilateral termination of the public law contract by the public authority. In such a case, the indemnification is based on the same principles set when the contractor or a third party obtains the voidness of a contract before an administrative court: the other party must at least be compensated in order to avoid unjust enrichment and can be fully compensated where it had no part in the illegality of the contract. ${ }^{72}$ Regarding the unilateral termination of the contract by a private party, it is only possible when a contractual clause so provides and with strong limitations set in 2014 by the Conseil d'Etat. Such termination is never possible for contracts whose subject matter is the performance of a public service mission and, for other contracts, the public authority can always oppose the termination on grounds of public policy. ${ }^{73}$

CE 20 January 1905, Compagnie départementale des eaux, no. 08248 , Leb. 55.

CE 12 November 2015, Société Le Jardin d'acclimatation, no. 387660.

CE Ass. 2 May 1958, Distilleries de Magnac-Laval, no. 32401, Leb. 246.

See CE Sect. 22 January 1965, Société des établissements Michel Aubrun, no. 59122, Leb. 50, CE Ass. 29 April 1994, Colombani, no. 105401, Leb. 209 and CE 10 January 1902, Compagnie nouvelle du Gaz de Deville-lès-Rouen, no. 94624, Leb. 5.

70 CE 31 July 1996, Société des téléphériques du massif du Mont-Blanc, no. 126594, Leb. 334.

${ }^{71}$ Ibid.

72 CE 10 July 2020, Société comptoir Négoce Equipement, no. 430864.

73 CE 8 October 2014, Société Grenke location, no. 370644. 


\subsubsection{Exceptions to the Binding Force of Contracts Benefiting Private Contractors}

Some exceptions benefit private contractors. The theories at stake set by the case law ensure some right to damages in spite of the absence of any legal text or clause which could support them. One may notice nonetheless that the underlying basis of those rights is not public generosity but the continuity of the public service - so they are a sort of win-win.

Imprévision comes first to mind. As stressed by Paul Craig, it is similar to frustration but with notable differences, the main one being that in principle it does not lead to the termination of the contract. ${ }^{74}$ Introduced in 1916 by the famous case of Gaz de Bordeaux, it is a landmark of the differences between public law contract and private law contract, the latter being totally reluctant to this idea until the Ordinance 10 February 2016 introduced in art. 1995 of the Civil Code as a pale copy of the administrative law theory of imprévision. ${ }^{75}$ The 1916 case was related to a concession, but the case law extends the concept to other contrats administratifs such as public procurement contracts. It remains uncertain whether it should apply to contracts with no link at all with a public service mission such as conventions d'occupation du domaine public. The Gaz de Bordeaux case stated

In principle, the concession contract regulates the respective obligations of the concessionary and the grantor in a definitive manner until its expiry ... The increase which has occurred during the present war in the price of coal, which is the raw material for the manufacture of gas, has reached such a proportion that not only is it exceptional in the sense usually given to this term, but that it entails an increase in the cost of the manufacture of gas which, to an extent which defies all calculations, certainly exceeds the extreme limits of the increases which could have been envisaged by the parties at the time of the conclusion of the concession contract; that, as a result of the combination of the above-mentioned circumstances, the economic substance of the contract has been completely overturned.

The latter concept, called bouleversement de l'économie du contrat ('overturning the economy of the contract'), is the core element of the theory. For concessions, it means that an unforeseeable event causes a deficit. For public procurement contracts, it means extra costs which go beyond the normal prediction, the threshold of which varies in the case law between approximately 7 per cent and 12 per cent of the agreed price. The unforeseeable events are not limited to wars,

74 Craig, 'Specific Powers of Public Contractors', p. 175.

75 CE 30 March 1916, Compagnie générale d'éclairage de Bordeaux, no. 59928, Leb. 143. 
but have extended to the German occupation during Second World War, the events of May 1968 in Paris, the 1973 oil crisis, exceptional storms or new regulations, etc., as long as they are external to the parties. ${ }^{76}$ Imprévision has not played an important role in recent decades because most public contracts added clauses to limit the impact of economic turmoil. But the Covid-19 pandemic will probably give this theory a rebirth. Another underlying condition was made explicit in 1982: the contractor must continue the performance of the contract which confirms that the basis of the theory is the continuity of the public service. ${ }^{77}$ The consequence of imprévision for the contracting authority is a duty to pay damages which amount between 80 and 95 per cent of the loss, depending on the behaviour of the contractor and its past and future benefits. ${ }^{78}$ The idea is to keep the contractor at risk to a certain extent. For this reason, the case law admitted in 1932 that, if the imbalance of the contract becomes permanent because of this unforeseen event, both parties are entitled to ask the competent administrative court to terminate the contract (with no damages), which is sometimes called force majeure administrative. ${ }^{79}$ This must not to be confused with force majeure, which, like in private law, entitles any contractor to get rid of its contractual obligations either temporary or permanently. Like imprévision, force majeure involves an unforeseeable event, external to the parties but which is also compelling (événement irresistible).

The situation is different regarding the fait du prince theory in administrative law, in terms of both the conditions and the consequences. The consequences are straightforward. The duty of the contracting authority is to compensate its contractor fully. The conditions are quite simple: the event is not exterior to the party because the source of the damage lies in the action of the contracting authority, but in its capacity of a public authority - that is, in its public interest role and not as a contractor. For instance, the state must pay damages for the land of which a company was deprived despite the contractual expectations, due to a modification of the urban planning regulation made by the state. ${ }^{80}$ If the shift in regulation causing harm comes from another public authority, the victim can turn to the imprévision theory but will have lower damages for the reason explained previously.

$7^{6}$ Regarding the potential use of this theory in the Covid-19 context, see F. Lichère, F. Akoka, A. Meynier-Pozzi and V. Lamy, 'Crise sanitaire et contrats publics, une approche de sociologie juridique' AJDA 2021, 1425.

77 CE Sect. 5 November 1982, Société Propétrol, no. 19413, Leb. 381.

$7^{8}$ A. De Laubadère, F. Moderne and P. Delvolvé, Traité des contrats administratifs, 2 vols. (Paris: LGDJ, 1984), vol. 2, p. 624.

79 CE 9 December 1932, Compagnie des tramways de Cherbourg, no. 89655, Leb. 1050; CE 14 June 2000, Commune de Staffelfelden, no. 184722, Leb. 227, for permanent pollution.

8o CE 29 December 1997, Société civile des Néo-Polders, no. 146753. 
Finally, the case law introduced two other theories challenging the binding force of contracts, but applicable to public procurement contracts only, probably because concessions imply more risks on the concessionary's part. The unforeseen situations (sujétions imprévues) are

material difficulties encountered in the performance of the contract, of an exceptional nature, unforeseeable at the time of conclusion of the contract and whose cause is external to the parties. ${ }^{81}$

This is notably the case where exceptionally difficult terrain is discovered in the course of public works.

The last theory concerns works (or services) which are essential for the proper execution of the works included in the public procurement contract plan. ${ }^{82}$ Compensation can be provided for oral instructions which were never confirmed in writing or, more frequently, for works which follow from the nature of the activity (règles de l'art). ${ }^{8}{ }_{3}$ However compensation cannot be awarded if the contracting authority is clearly opposed to them. ${ }^{84}$

\subsection{REMEDIES FOR PUBLIC LAW CONTRACTS}

As seen in Chapter 4, remedies before administrative courts are mainly either annulment in judicial review (the recours pour excès de pouvoir), or a variety of powers entrusted to the courts in the recours de plein contentieux or de pleine juridiction. Contract litigation belonging to the latter prevails, since the case law lays down as a strong principle the impossibility to exercise a judicial review in relation to a contract. Two exceptions were laid down in the 1990s and survived the introduction of new remedies of plein contentieux in the twenty-first century. The first one is more of an exception which confirms the principle rather than being a real exception. In the 1996 case Cayzeele, the Conseil d'Etat held that regulatory clauses - that is, clauses which have an effect on third parties - can be challenged by interested third parties. ${ }^{85}$ In the case, a landowner was able to challenge a clause in a rubbish collection concession which required the concerned owners - who were third parties to the concession - to buy specific containers. This case is in line with a case decided eighty years earlier where the Conseil d'Etat allowed judicial review

\footnotetext{
CE 30 July 2003, Commune de Lens, no. 223445, Leb. 862.

CE 9 September 2010, Société Babel, no. 319481.

CE Sect. 17 October 1975, Commune de Canari, no. 93704, Leb. 516.

CE 27 March 2020, Société Géomat, no. 426955.

CE Ass. 10 July 1996, Cayzeele, no. 138536, Leb. 274.
} 
against a unilateral act on the grounds that it was contrary to a regulatory clause contained in a concession. ${ }^{86}$

In the 1998 Ville de Lisieux case, the Conseil d'Etat allowed the recours pour excès de pouvoir of third parties against contracts for the recruitment of public agents. However, the standing for this action is higher than usual, since the third party must have a 'sufficient interest' which is the case for members of a city council against the recruitment by contract decided by the mayor. ${ }^{87}$ Recours pour excès de pouvoir from third parties was also admissible against a separable unilateral administrative act from a contract (whether of public law nature or not). But nowadays this is rarely used since the Conseil d'Etat introduced a new remedy for third parties. In this matter, one must distinguish between contracting parties and third parties.

\subsubsection{Remedies for Third Parties to Public Law Contracts}

Administrative contracts may be concerned with remedies available to third parties introduced as a result of the transposition of the EU review directives, which give important powers to the courts including setting aside decisions regarding the award of public procurement contracts or concessions (référé précontractuel, art. L551-1 CJA) or the contract itself (référé contractuel, art. L551-13 CJA). But civil courts are also concerned with the same remedies, since the relevant EU directives apply to contracts considered private law contracts under French law and subject to the jurisdiction of the civil courts. Moreover, those remedies are open only to public procurement contracts and concessions and not to other contrats administratifs, even if subject to an open award procedure such as the contracts for the occupation of public property (conventions d'occupation du domaine public). ${ }^{88}$ As a consequence, we will focus on the other remedies which are all recours de plein contentieux, whether they concern damages or other powers attributed to the courts.

In France, damages for a wrongfully rejected bidder in administrative award procedures are quite generous when compared with other jurisdictions. ${ }^{89}$ Three situations are envisaged. If the bidder had no chance of winning the contract (lack of capacity, for instance), he will not be compensated. If he was not deprived of any chance to win the contract (a valid bid but badly ranked), he will have its bid costs compensated. If he had a serious chance of winning

86

87

88

89

CE 21 December 1906, Syndicat des propriétaires et contribuables du Quartier de Croix-deSeguey-Tivoli, no. 19167, D. 1907.3.41 concl. Romieu.

CE Sect., 30 October 1998, Ville de Lisieux, no. 149663, Leb. 375.

CE 30 April 2019, Société Total Marketing France, no. 426698.

D. Fairgrieve and F. Lichère, eds., Damages as an Effective Remedy (London: Hart, 2011). 
the contract (he was very likely to win had the illegality not occurred), he will be compensated for the loss of profits. ${ }^{9}$

But the most notable recours de plein contentieux is the judge-made remedy created in 2007 and extended in 2014, sometimes called the recours Tropic/ Tarn et Garonne. ${ }^{91}$ Any interested third party can challenge the validity of a public law contract, but two sets of rules secure the contract to a limited extent. Unlike local state representatives, the prefects, and members of the local assemblies for local public contracts, third parties must prove that they have suffered or are likely to have suffered from a breach of law. Moreover, any illegality would not force a court to order annulment or termination, because it can decide whether to maintain the contract, to terminate it or to annul it, depending on the seriousness of the unlawfulness, the possibility to regularise it and the public interest in maintaining the contract.

Finally, the Conseil d'Etat transformed in 2017 a recours pour excès de pouvoir into a recours de pleine juridiction regarding a refusal to terminate a public law contract. ${ }^{2}$

A third party to a public law contract likely to be prejudiced in a sufficiently direct and certain way by a decision refusing to grant his request to terminate the performance of the contract, shall be entitled to bring before the contract judge an action of full jurisdiction seeking the termination of the contract.

The reason for this change is to preserve legal certainty since there are strong limitations on the admissible legal arguments. Not only must the invoked unlawfulness prejudice the claimant, but only three legal arguments may be invoked: the contract must be terminated because of new legislative provisions applicable to current contracts, or the contract is vitiated by irregularities which are of such a nature as to preclude its continued performance and which the court should raise of its own motion, or that continued performance of the contract is manifestly contrary to the public interest.

\subsubsection{Remedies for Parties to Public Law Contracts}

Damages are the main remedy regarding contractors and the reason for this is in line with the privilège d'action d'office (the state's privilege to act as it thinks

$9 \circ$ CE 18 June 2003, Groupement d'entreprises solidaires ETPO Guadeloupe, no. 249630, Leb. 865 .

91 CE Ass. 16 July 2007, Société Tropic Travaux Signalisation, no. 291545, Leb. 360 concl. Casas; CE Ass. 4 April 2014, Département du Tarn-et-Garonne, no. 358994, Leb. 70 concl. Dacosta.

92 CE Sect. 30 June 2017, Syndicat mixte de promotion de l'activité transmanche (SMPAT), no. 398445 . 
necessary). For a long time, the Conseil d'Etat considered that damages were the only remedy available for private contractors who cannot challenge decisions taken by public authority contractors in the course of the performance of the contract, because this would block public action. By way of exception, the private contractor can now challenge the decision to terminate the contract since the 2011 Béziers II case and even asks for its suspension (art. L521-1 CJA), the latter being rarely granted because suspension requires the matter to be urgent. ${ }^{93}$ But it has not gone further - and one may even challenge the idea that termination relates to the performance of a contract. The Conseil d'Etat has so far not allowed a challenge to other decisions concerning performance, including a unilateral change of contract. ${ }^{94}$

Most damages actions concern bad performance of the contract, including against contracting authorities when they manage the contract poorly in a manner that delays the works to be done. ${ }^{95}$

If the contract is declared void, two damages actions are available to the private contractor. The contractor can seek damages for the unjust enrichment of the public contractor (responsabilité quasi-contractuelle) which does not require any proof of a fault. In addition, where the unlawfulness was the consequence of a fault of the public authority, the contractor may seek full compensation, including the loss of profits (responsabilité quasi-délictuelle). ${ }^{6}$ If the private contractor contributed to the illegality or could not reasonably ignore it, the fault is mutual, and the courts tend to split the liability, but exceptionally it leads to the full liability of the private contractor. ${ }^{97}$

As for public contractors, since they can use their own powers to secure performance (pouvoir d'exécution d'office), they can order their contractors to pay a sum (à titre exécutoire) as soon as they consider themselves creditors. However, the Conseil d'Etat made an exception to the principle by which a public authority cannot bring an action in an administrative court if it itself has the power to act unilaterally if brings an action for damages against a private contractors. ${ }^{9}$ In addition, the Conseil d'Etat tends to extend the jurisdiction of administrative courts regarding damages sought by the administration against a private person on a non-contractual basis, despite the ment (réparation en nature) awarded to a contractor against a public body: CE Sect. 6 December 2019, Société des copropriétaires de Montecarlo Hill, no. 417167, RFDA 2020, 121 concl. Pellisier and 333 note Petit.

96 CE 23 May 1979, Commune de Fontenay-le-Fleury, no. ooo63, Leb. 226.

97 CE Sect. 10 April 2008, Société Jean-Claude Decaux, no. 244950, Leb. 152.

$9^{8}$ CE 24 February 2016, Département de l'Eure, no. 395194. 
principle of jurisdiction of civil courts, every time there is a link with public law contracts. We have seen this tendency regarding damages for illicit collusion, but its scope is wider. ${ }^{99}$

The other remedy available concerns the challenge to the validity of the contract by contractors. Until 2009, it was widely accepted that a party could seek the annulment of a public law contract from an administrative court for almost any illegality but the Conseil d'Etat reduced its scope in the name of the newly created principles of contractual loyalty and contractual stability in the so-called Béziers I case. ${ }^{100}$ Since then, the courts apply the same reasoning as in Tarn-et-Garonne with regard to the consequence of an illegality and take into consideration the seriousness of the breach, the possibility to regularise it and the public interest in maintaining the contract. When the validity is challenged in the course of contractual litigation already brought before a given court, the contractors can only seek annulment for illicit content or very serious unlawfulness. This is a high bar which requires more than the simple illegality of the award. The award must have been made on purpose clearly to favour a bidder in such a way that it is similar to a criminal offence. ${ }^{101}$ One may notice that French law created in 1991 a specific criminal offence for favouritism in the course of awarding a public procurement contract or a concession (art. 413-14 of the Criminal Code).

It should be recalled that since the 2020 Société comptoir négoce équipements case, the public contractor may decide to terminate the contract in case of serious unlawfulness of the contract but can still ask the judge to annul the contract or to terminate it. ${ }^{102}$

On the whole, remedies available to third parties and remedies available to public authority contractors are currently converging - though not merging. The common trend lies in the balance between redressing unlawfulness and maintaining public law contracts. The development of several recours de plein contentieux in this area by the Conseil d'Etat gives the core role of setting the right balance in the hands of the administrative courts themselves.

\subsection{CONCLUDING REMARKS}

Contemporary French administrative law on public contracts is a product of history and tradition. However, the rules set by long-standing case law are

99 See note $3^{8 .}$

100 CE Ass. 28 December 2009, Commune de Béziers, no. 304802, Leb. 509.

101 CE 11 January 2011, Manoukian, no. 338551, Leb. 5.

102 See note 72. 
nowadays challenged by academic writings and by European and international laws.

The academic challenges started with concerns about the modernity of specific powers to contractors and more generally doubts the compatibility of the exceptions to the binding force of contracts with the very essence of contract. The power to change public law contracts unilaterally led one author to ask the following: can public law contracts be deemed the 'law of the administration', a reference to the Civil Code rule according to which contracts are the law of the parties? ${ }^{103}$ Asking the question was already giving the answer. One famous author even suggested assigning all public contracts to civil courts. ${ }^{104}$ No such debates happen today. But there are tensions between keeping the specificities of public contracts as much as possible and reducing the differences with private law contracts when possible. One example of this tension may be seen in the implementation of good faith to public contractors which is challenged by a rapporteur public and a professor on the ground that civil courts use the principle of good faith (bonne foi) to sanction the abuse of the exercise of contractual prerogatives and to guarantee the principle of equality between parties, which is contrary to contrats administratifs. ${ }^{105}$ However, the Conseil d'Etat now seems to accept to verify whether a contracting authority acted in good faith during the performance of the contract. $^{106}$

Moreover, French law is now shaped by European and international trends which produced some effects on public contracts law. At the international level, if the Organisation for Economic Co-operation and Development (OECD) does not play a great deal in this field, the World Trade Organization (WTO) Agreement on Government Procurement (GPA) was signed in 1994 as part of the Marrakech agreements, as a plurilateral agreement by all the EU Member States and by nineteen other states and was approved by Council Decision 94/80o/EC. The aim of the GPA is to establish a multilateral framework of balanced rights and obligations relating to public contracts with a view to achieving the liberalisation and expansion of world trade. In concrete terms, it has an impact on which public procurement contracts are opened to firms originated from the signatory states and

\footnotetext{
103 J. L’Huillier, 'Les contrats administratifs tiennent-ils lieu de loi à l'administration?', D. 1953, chr. 87 .

104 Roland Drago, 'Le contrat administratif aujourd'hui', Droits 1990 no. 12, p. 117.

105 G. Pellissier, conclusions on CE 7 December 2015, Syndicat Mixte de Pierrefonds, no. 382363 ; see also J.-F. Sestier, 'La loyauté dans l'exécution des relations contractuelles: un standard juridique commode?’, in Mélanges Richer (Paris: LGDJ, 2013), p. 451.

106 CE 10 February 2020, SAEM, no. 422063.
} 
encourages the application of EU public contracts directives to economic operators of third countries that are signatories to the agreements. It also affects the thresholds above which public contracts award notices must be published in the Official Journal of the EU. Those thresholds are expressed as special drawing rights, a combination of the main currencies. The thresholds laid down by the European directives on public contracts are aligned to ensure that they correspond to the euro equivalents of the thresholds of the GPA and periodic reviews of the thresholds expressed in euros are made by means of a purely mathematical operation so as to adjust them to possible variations in the value of the euro in relation to those special drawing rights.

But in terms of influence over public contracts, WTO rules cannot compete with EU law. European Union directives on public procurement contracts, adopted in the 1970 o for works and supplies (and in 1992 for services) and amended in 1989, 2004 and 2014, has had a direct effect on French public contracts law albeit largely inspired by the French Public Procurement Code. ${ }^{107}$ The main effect has been on the scope of the award procedures rules. Limited to public authorities under the 1964 Code des marchés publics (with the exception of those with industrial and commercial activities which do not handle public money), rules on the award now extend to any bodies governed by public law or associations formed by one or more such authorities or one or more such bodies governed by public law as laid down in the directives. These include many entities considered of private law nature under French law such as mixed capital companies. Moreover, certain contracts deemed as excluded from those rules in relation to the importance of the individual characteristics of the contractor (the principle of intuitu personae) now fall into their scope because of EU law. This is notably the case in agency contracts whose exclusion from the Code des marchés publics by a 2001 decree was overruled by the Conseil d'Etat as contrary to EU directives. ${ }^{108}$ Even more topical was the case of public procurement contracts between public authorities. For the Conseil d'Etat those contracts were possible without award procedures under traditional practice, explicitly allowed by a 1974 guideline on the implementation of the 1964 Code. But EU law made it impossible to sustain this position, so the Conseil d'Etat deemed those contracts public procurement contracts when they are above the European thresholds but not

107 P. Terneyre, 'L'influence du droit communautaire sur le droit des contrats publics', AJDA, 1996, 84; F. Lichère, 'L'influence du droit communautaire sur le droit français des contrats publics', in J. Dutheil de la Rochère and J.-B. Auby, eds., Droit administratif européen (Bruxelles: Bruylant, 2007), p. 945.

108 CE 5 March 2003, UNSPIC, no. 233372, Leb. 108. 
when they are below. ${ }^{109}$ This peculiar reasoning was abandoned by the government with the adoption of the 2001 Public Procurement Code which defined economic operators as of private or public nature whatever the amount of the contract was. But it revealed that the rationale of applying award procedural rules shifted, because of EU law, from an approach in favour of contracting authorities, with the aim at protecting them from firms which may abuse the lack of knowledge of civil servants, to one in favour of economic operators - with the aim at securing in practice the free movement principles by extending formal rules which render difficult the temptation to buy nationally (or locally). Bearing this in mind, EU law influences to a certain extent not only the scope but also the substance of the rules. For instance, French law used to deal with abnormally law offer in a flexible manner. Contracting authorities had the power to set aside such offers but it was not made mandatory since it was for them to decide whether they take the risk of bad performance of the contract - or even non-performance in case of insolvency. The Court of Justice of the European Union (CJEU) made it obligatory by considering that, if a tenderer offers an abnormally low price, the contracting authority must ask in writing to clarify its price proposal.

That authority must treat the various tenderers equally and fairly, in such a way that a request for clarification cannot appear unduly to have favoured or disadvantaged the tenderer or tenderers to which the request was addressed, once the procedure for selection of tenders has been completed and in the light of its outcome. ${ }^{110}$

Regarding concessions, the influence is even more prominent. Nonetheless, France had anticipated the EU directive 2014/23/EU on concessions many years prior to its adoption on the 26 February 2014 with the Loi Sapin of 29 January 1993. The latter put in place obligations of transparency which left contracting authorities with a wide margin of appreciation for choosing their concessionaires. But the transposition of the directive 2014/23/EU clearly assimilates the award of concessions to that of public procurement contracts, which may compromise the implicit idea that concession awards are to be made upon the intuitu personae principle. ${ }^{11}$

109 CE 20 May 1998, Communauté de communes du Piémont de Barr, no. 188239, RFDA 1998, 6o9, concl. Savoie.

11 CJEU 29 March 2012, Case C-599/10, SAG ELV Slovensko a.s. ECLI:EU:C2021:191. The same solution was adopted just before by the Conseil d'Etat on the ground of equality albeit the Code clearly stated that the contracting authority 'may' reject an abnormally low offer, CE 1 March 2012, Département de la Corse du Sud, no. 354159.

111 On this particular issue, see F. Lichère, 'La passation des concessions', AJDA 2016, 1000. 
European Union rules may produce an indirect effect on specific powers granted to public authorities. This is notably the case concerning the unilateral power of modification which, for public procurement and concessions contracts, must now fulfil the limits set by the case law of the European Court of Justice (ECJ) in 2008 and subsequently framed in art. 72 of directive 2014/24/ EU. ${ }^{112}$ The new Code de la commande publique (CCP) makes clear that these rules apply to any amendment (avenant) and, when it comes to contrats administratifs, both for consensual and unilateral modifications. ${ }^{113}$ It is even probably the case for financial compensation for imprévision, sujétions imprévues and fait du prince. Often considered as extra-contractual damages which may or may not lead to an amendment, they should be considered as a modification if one takes a thorough look at the Finn Frogne case: ${ }^{.14}$

A material amendment cannot be made to that contract without a new tendering procedure being initiated even in the case where that amendment is, objectively, a type of settlement agreement, with both parties agreeing to mutual waivers, designed to bring an end to a dispute the outcome of which is uncertain, which arose from the difficulties encountered in the performance of that contract. 'Material' must be understood here as 'significant' since in the French version the adjective used is 'substantiel', which may therefore include amendments which are purely financial ones as may be indemnification of imprévision for instance.

Interestingly, an example of 'gold plating' - that is, of over implementation, may, on the contrary, reinforce the powers of contracting authorities. ${ }^{115}$ Article 57 , para. $4 \mathrm{~g}$ of directive $2014 / 24 / \mathrm{EU}$ states that contracting authorities may exclude from participation in a procurement procedure any economic operator 'where the economic operator has shown significant or persistent deficiencies in the performance of a substantive requirement under a prior public contract, a prior contract with a contracting entity or a prior concession contract which led to early termination of that prior contract, damages or other comparable sanctions'. When transposing the directive, the French government decided to add to this potential exclusion during the award phase the possibility to terminate the contract if the contractor had faced or

112 ECJ 19 June 2008, Case C-454/o6, Pressetext Nachrichtenagentur, ECLI:EU:C:2008:351.

113 Articles L2194-1 CCP for public procurement contracts and L3135-1 CCP for concessions.

114 CJEU 7 September 2016, Case C-549/14, Finn Frogne A/S, ECLI:EU:C:2016:634.

115 F. Lichère, "The Transposition of the Public Procurement Directive in France: Between Over Implementation and Questionable Implementation', in S. Treumer and M. Comba, eds., Modernising Public Procurement: The Approach of EU Member States (London: Elgar, 2018), pp. 93-111. 
even faces this situation during the performance phase. Obviously, such a power may represent an important threat to private contractors.

However, it remains uncertain whether in practice the EU rules led to significant changes in the habits of public authority contractors regarding the use of their unilateral powers.

More generally one may think that the insistence of legal scholars on extracontractual powers of public contractors may not represent the reality of contractual relationships which are probably shaped on a daily basis around the contract terms. If parties to public law contracts are unequal, this also stems from the unilateral formation of the contract and from the content of those contracts which ensures strong powers to public contractors especially through the use of standard terms and conditions, as it is the case in common law countries. ${ }^{116}$ Contrats administratifs are agreements of the will between unequal parties, but the source of this inequality is certainly diverse in France. ${ }^{117}$

116 N. Gabayet, L'aléa dans les contrats publics en droit anglais et droit français (Paris: LGDJ, 2015).

${ }^{11}$ L. N. Brown and J. Bell, French Administrative Law, $5^{\text {th }}$ ed. (Oxford: Oxford University Press, 1998), p. 192. 